Journal for the Study of the Old Testament

Vol 40.4 (2016): 399-413

(C) The Author(s), 2016. Reprints and Permissions:

http://www.sagepub.co.uk/journalsPermissions.nav

DOI: $10.1177 / 0309089215611532$

http://JSOT.sagepub.com

\title{
On Dying in a City Gate: Implications in the Deaths of Eli, Abner and Jezebel
}

\section{CAT QUINE}

Worcester College, Walton Street, Oxford OX1 2HB

\begin{abstract}
Recent research has shown that city gates were a place of judgment, execution, and public displays in ancient Israel and the ancient Near East. This article explores the role of the gate on the literary level in the narratives concerning the deaths of Eli, Abner and Jezebel. It demonstrates how the function of gates in ancient Israel, and the institutions associated with them, allow the narrator to draw on themes of judgment, punishment and order, as well as creating a sense of irony throughout.
\end{abstract}

Keywords: City gates, death/execution, irony/rhetoric, Eli, Abner, Jezebel, justice.

\section{Introduction}

Two recent publications on city gates in the Hebrew Bible and ancient Israel have caught the eye. ${ }^{1}$ What follows is concerned with applying

1. Natalie N. May, 'Gates and their Functions in Mesopotamia and Ancient Israel', in Natalie N. May and Ulrike Steinert (eds.), The Fabric of Cities: Aspects of Urbanism, 
these new conversations about the role and function of ancient Israelite city gates to the biblical texts in a socio-historical manner, and, in so doing, it draws attention to the way in which the author in 1 and 2 Samuel and 2 Kings uses gates on a literary level. As will be demonstrated, city gates were a place of judgment, execution, and public displays in ancient Israel and the ancient Near East, and so it should be of some interest when a notable character in biblical narrative is reported as having died 'in a gate'. In line with this it seems plausible that in a text reporting a death in a gate, we need to understand what a gate was, what it meant, what it symbolized, and what some of the cultural values attached to it were. Then we must view our dying character the same way: who they were, what they did, what they symbolized and the cultural (or narrative) impact of their death. To do so, I will first outline some of the functions of city gates in ancient Israel, before turning attention to three examples: the death of Eli (1 Sam. 4.13), the death of Abner (2 Sam. 3.27), and the death of Jezebel (2 Kgs 9.31-33).

\section{City Gates in Ancient Israel}

The term שער can refer to the area inside the gate building (2 Sam. 3.27), the area between the inner and the outer city gates, a public square inside the city next to the gate, or possibly a gathering place just outside the city (2 Sam. 18.4; 19.8; $1 \mathrm{Kgs} 22.10$ ), or a specific gate inside a city (e.g. 2 Kgs 14.13; Neh. 3.3). ${ }^{2}$ Geus also notes that 'By understanding the gate complex, consisting of two gates with an open space between them, as one unit, archaeologists nowadays interpret such a gate complex as the largest public building of an Iron Age town in these parts of the ancient Near East'. ${ }^{3} \mathrm{He}$ also notes that the gates are thus the centre of social, economic and administrative matters, where "whoever wants to know

Urban Topography and Society in Mesopotamia, Greece and Rome (Leiden: E.J. Brill, 2014), pp. 77-121; Carey Walsh, 'Testing Entry: The Social Functions of City-Gates in Biblical Memory', in Diana V. Edelman and Ehud Ben Zvi (eds.), Memory and the City in Ancient Israel (Winona Lake, IN: Eisenbrauns, 2014), pp. 43-61.

2. A full list of references can be found in BDB, pp. 1044-45.

3. C.H.J. Geus, Towns in Ancient Israel and in the Southern Levant (Palaestina Antiqua, 10; Leuven: Uitgeverij Peeters, 2003), p. 34; David Ussishkin, 'The City-Gate Complex', in David Ussishkin (ed.), The Renewed Archaeological Excavations at Lachish 1973-1994 (Monograph Series of the Institute of Archaeology, Tel Aviv University, 22; Tel Aviv: Emery and Claire Yass Publications in Archaeology, 2004), pp. 504-34. 
what is going on in a town talks with people in the gate'. ${ }^{4}$ Interestingly, the gate as a place of gossip is also noted in Ps. 69.12: 'I am the subject of gossip for those who sit in the gate'. The size of the gate, as well as public spaces or squares often being next to them, means that they were naturally, in many Israelite cities, the place where people would gather. In terms of archaeological evidence, Beersheba, Lachish, Tel Dan, Gezer and Megiddo all provide useful examples. ${ }^{5}$

May has provided a list of nine functions of city gates in ancient Israel and the ancient Near East in her recent article, but here we can only pay particular attention to two of them:

1. Gates as a place for judicial activities - judgment, litigation, legal agreements, publication of court decisions and legal documents.

2. Gates as a place for public executions (not only of legal character). ${ }^{6}$

In the biblical texts, judgment and disputation is commonly enacted at city gates by various groups, including the elders. ${ }^{7}$ Recognition of this can be found variously in commentaries on these verses in the biblical texts as well as in studies dealing more with archaeological evidence of gates, or differently, studies on law and justice. ${ }^{8}$ Hertel has noted the old Assyrian

4. Geus, Towns in Ancient Israel, p. 33.

5. Z. Herzog, 'Beersheba', in Ephraim Stern (ed.), The New Encyclopaedia of Archaeological Excavations in the Holy Land (Jerusalem: The Israel Exploration Society, 1993), pp. 161-73; see also Z. Herzog, Archaeology of the City: Urban Planning in Ancient Israel and its Social Implications (Tel Aviv: Emery \& Claire Yass Archaeology Press, 1997), p. 246; Geus, Towns in Ancient Israel, p. 34; Y. Aharoni, 'Excavations at Tel Beer-Sheba', BA 35 (1972), pp. 111-27; A. Kempinksi, Megiddo: A City State and Royal Centre in North Israel (Munich: C.H. Beck, 1989); I. Finkelstein, David Ussishkin and Baruch Halpern (eds.), Megiddo IV: The 1998-2002 Seasons (Tel Aviv: Emery \& Claire Yass Publications in Archaeology, 2006). See also A. Biran, 'Tel Dan', BA 37 (1974), pp. 26-51; A. Mazar and G.I. Kelm, 'Tel Batash (Timnah)', in Stern (ed.), The New Encyclopaedia, pp. 152-57; J.R. Zorn, 'Tel en-Nasbeh', in Stern (ed.), The New Encyclopaedia, pp. 1098-102.

6. May, 'Gates and their Functions', p. 78. The other functions are: as a sacral or cultic space, a place for installation of royal monuments, a place of military or ritual procession, a place of public appearance of the king, a place of public assemblies, a market place, and a place of control.

7. Gen. 19.1; 23.10; Deut. 1.1-2, 19; 22.15; 25.7; Ruth 4.11; Jer. 26.10; Isa. 29.21; Amos 5.10, 12, 15.

8. May, 'Gates and their Functions', p. 95; Bruce V. Malchow, Social Justice in the Hebrew Bible (Collegeville, MN: Liturgical Press, 1996), p. 14; Walsh, 'Testing Entry', pp. 49, 54; Geus, Towns in Ancient Israel, p. 36; Frank S. Frick, The City in Ancient Israel 
'judges of the step gate' as well as the reference in CCT $5,18 \mathrm{~d}$ to 'the gate of God' being a place for arbitration or another law court. ${ }^{9}$ May convincingly demonstrates that in Mesopotamia the gates were a place of judgment, and the orders of the judge were carried out there, meaning that torture and executions would have been visible. ${ }^{10}$ She notes that the Assyrian inscriptions demonstrate a practice of executing prisoners of war and displaying their heads in the gate, and that Sennacherib and Esarhaddon imprisoned disloyal kings at their gates to be mocked by a mob. ${ }^{11}$ The biblical texts also attest to similar practices: 2 Kgs 10.8 narrates the piling of the heads of the king's sons at the gates; Jer. 20.2 has Jeremiah being placed in stocks at the Upper Benjamin gate; and the elders in Deuteronomy commonly give judgment and see people punished or executed at the gates (Deut. 17.5;21.1-2, 19;22.15). The punishing of criminals in the gate also attests to the public nature of the gatescriminals are punished there as a visible example to the many people that would pass by them. The Assyrian practice of punishing miscreant kings or prisoners of war in such a public location also serves to reinforce the king's power, or the community rules, to all those who witnessed such events. With these characteristics of city gates in mind, of judgment, punishment or execution of criminals and public reinforcing of order, we perhaps start to see the references to certain biblical characters reported to have died in a gate in a different light. Matthews notes: 'Since justice is generally conceived to have originated with a god or gods, both physically and metaphorically the gate provided a link between two

(Missoula, MT: Scholars Press, 1977), pp. 120-22; William G. Dever, The Lives of Ordinary People: Where Archaeology and the Bible Intersect (Cambridge, MA: Eerdmans, 2012), p. 137; Biran, 'Tel Dan', p. 45; Thomas Hertel, Old Assyrian Legal Practices: Law and Dispute in the Ancient Near East (Leiden: Nederlands Instituut voor het Nabije Oosten, 2013), pp. 316-29; Pietro Bovati, Re-Establishing Justice: Legal Terms, Concepts and Procedures in the Hebrew Bible (trans. Michael J. Smith; Sheffield: JSOT Press, 1994), p. 232; Hans Jochen Boecker, Law and the Administration of Justice in the Old Testament and Ancient East (trans. Jeremy Moiser; London: SPCK, 1980), p. 31; Bernard M. Levinson, Deuteronomy and the Hermeneutics of Legal Revision (Oxford: Oxford University Press, 1997), pp. 125-26; J. Gray, 'The goren at the City Gate: Justice and the Royal Office in the Ugaritic Text “Aqht”, PEQ 85 (1953), pp. 118-23; Victor H. Matthews, 'Entrance Ways and Threshing Floors: Legally Significant Sites in the Ancient Near East', Fides et Historia 19 (1987), pp. 25-40.

9. Hertel, Old Assyrian Legal Practices, pp. 328-29.

10. May, 'Gates and their Functions', pp. 100-101. See Hertel's comments on the 'gate of God' in Assyrian litigation-Hertel, Old Assyrian Legal Practices, p. 329.

11. May, 'Gates and their Functions', pp. 101-102. 
realms of existence. The gate was the tie that bound the average citizen to the operations of his government and of the temple. And it was the symbol of the continuity of law and social stability. ${ }^{12}$ It is of little surprise then that public reinforcement of order and stability, achieved via the public law court and the carrying out of its judgments, was enacted in city gates. Perhaps this also contributes to explaining why the kings would on occasion in the biblical texts be sitting in the gate-sometimes they were serving as judges, but perhaps also their physical presence there served to demonstrate that the internal order was under control. ${ }^{13}$ Just as the gate acted as the boundary between the outsiders and the insiders, so it also served as the place of establishing internal order and security. Given the role of the gate as an entry point into a community or an exit into the outside world, an execution in the gate demonstrates that the person concerned has been cut off from the community permanently. I suggest that the people of the time would have recognized themes of judgment, punishment and order to be intertwined institutionally with gates in ancient Israel, and this, on the literary level, allows the biblical authors to make use of these themes in writing their narratives.

\section{The Death of Eli (1 Samuel 4.18)}

In v. 13 Eli is presented as ישב על־הכסא יד דרך מצפה, although in v. 18 this is explained more clearly as being (ויפל מעל־הכסא אחרנית) בעד ידבסדיד. השער. The textual issue with in v. 13 is solved by the versions following v. 18 and suggesting בעד יד was meant there also. In this case we would have in v. 13, 'Eli was sitting upon his throne by the side of the road watching', and in v. 18, 'and he fell backwards from upon his throne by the side of the gate'. The use of כסא is immediately interesting, as it generally denotes a throne or a seat of honour, as is the location of where Eli is sitting. In the books of Samuel and Kings, the only people described as 'sitting in the gate' are Eli, David (2 Sam. 18.24; 19.8), and the king of Israel and king Jehoshaphat of Judah (at the entrance of the gate, $1 \mathrm{Kgs}$ 22.10). Other notable characters appear around gates, though notably they do not sit in them: Absalom (by the road into the gate, 1 Sam. 15.2),

12. Matthews, 'Entrance Ways', p. 26.

13. 2 Sam. 18.4, 24, 33; 19.8; 2 Kgs 22.10; Jer. 38.7. McKeating has also suggested that the king in this role may have acted as a sort of 'public go ' $\mathrm{el}$ ', as a protector of those who did not otherwise have protection. Henry McKeating, 'The Development of the Law on Homicide in Ancient Israel', VT 25 (1975), pp. 46-68. 
Samuel (1 Sam. 9.18) and Joab/Abner (2 Sam. 3.27). In view of these comparisons, it seems unlikely to have been an accident that Eli is placed upon a כסא in the manner of the kings after him, only to fall off it backwards.

Whether Eli is sitting by the city gate, or by a temple gate, has been interpreted differently by scholars. ${ }^{14}$ The narrative gives no real indications either way, though 1 Sam. 1.9 has Eli ישב על־הכסא על־מזוזת היכל, which is where the temple interpretations have come from..$^{15}$ The movement within the narrative does not help us, as the messenger runs into the city and tells the people his news and then Eli hears, which seems a plausible chain of events if Eli is sitting by the temple, further on into the city, and so the messenger reaches the people first. Equally, we are told that Eli is blind and so had he been sitting by the city gate, he would not have seen the messenger run past him. Here I will be using the city-gate scenario for two reasons. First, there is no other reference to a tradition of sitting upon a seat by the temple other than the reference in 1 Sam. 1.9, whereas there is a known tradition of leaders, whether kings (in Samuel and Kings) or elders (in Deuteronomy and Ruth) sitting in a city gate. Secondly, on a biblical level, whether the temple in Shiloh had a gate is open to question, as $1 \mathrm{Sam} .1 .9$ only mentions Eli sitting by the doorpost. Finally, the archaeological evidence from Shiloh suggests that Shiloh was a religious temenos in Iron Age I, with a high degree of building planning and construction, public buildings found in Area $\mathrm{C}$, and no living dwellings uncovered at the site. ${ }^{16}$ This being the case, it might not be unreasonable to suggest that the gates of the 'city' of Shiloh were also in some way the gates to the temple - that is, to the cultic settlement. In fact, if the excavators are correct and Shiloh was indeed dominated by its cultic associations and function in this period, then one would have expected the gates to be a notable aspect of its layout, marking the crossing from the outside world into the cultic place, and there would

14. Temple: Hans Wilhelm Hertzberg, I and II Samuel: A Commentary (London: SCM Press, 1964), p. 49; A. Graeme Auld, I and II Samuel: A Commentary (Louisville, KY: Westminster/John Knox Press, 2011), p. 69; City Gate: Keith Bodner, 1 Samuel: A Narrative Commentary (HBM, 19; Sheffield: Sheffield Phoenix Press, 2008), p. 46.

15. Robert Alter, The David Story: A Translation with Commentary of 1 and 2 Samuel (London: W.W. Norton \& Co., 1999), p. 24.

16. Israel Finkelstein, 'The History and Archaeology of Shiloh from the Middle Bronze Age II to the Iron Age II', in Israel Finkelstein (ed.), Shiloh: The Archaeology of a Biblical Site (Monograph Series of the Institute of Archaeology, Tel Aviv University, 10; Tel Aviv: Institute of Archaeology of Tel Aviv University, 1993), pp. 371-94, esp. 386. 
have been no reason why Eli would not be found there. Perhaps the reference in 1 Chron. 9.26 to the Levites acting as chief gatekeepers to the sanctuary is also worth noting. Although a late reference, it supports the idea of Levites having a role in the gates, and if Shiloh was a cultic settlement in Iron Age I then the city gate or entrance would have had a similar function to a temple gate - which, it should be said, was not found during excavation. To have Eli presented in the gate of the city, therefore, does not seem an unreasonable reconstruction.

A first glimpse of irony in the passage comes with the mention of Eli 'watching' (v. 13) despite being blind (v. 15). The second, Bodner sees with Eli's asking for the 'word' from the battlefield (מה־היה הדבר בני), which he interprets as a reference to the word of Yahweh in 1 Sam. 2.2736 , where the sign of the fulfilment of Yahweh's word will be the death of Eli's two sons on the same day (1 Sam. 2.34). In 1 Sam. 4 the messenger reports the death of Eli's sons, the narrator thus demonstrating in the messenger's words the fulfilment of the earlier words of the man of God. ${ }^{17}$ Commentators have differed with what to do with the reference to Eli having judged Israel for forty years at the end of 1 Sam. 4.18. Some, like Alter, have seen it as language carried over from the book of Judges, whether accidentally or deliberately. ${ }^{18}$ Robinson has suggested it may be taken as preparing the ground for presenting Samuel as a judge in 1 Sam. 7.15. ${ }^{19}$ Jobling has suggested that it is ironically presenting Eli as a failed judge: 'the irony is made complete by the Philistines; instead of Eli's being "raised up" to defeat them it is his corrupt regime that brings them back from their long absence to defeat him (1 Samuel 4)!' ${ }^{20}$ It seems that these are all good points, and that they can be taken together without contradiction. It is reasonable that our author may have been setting the stage for Samuel's judgeship, as well as making an ironic point about Eli's failures, and at the same time the language of forty years is stereotypical enough to suggest it may have been a stylistic device as well. Another aspect requiring consideration, however, is that of the gate. The fact that Eli sits at the gate and is referred to as having judged Israel cannot be lightly ignored when we recall the role of gates in judgment

17. Bodner, 1 Samuel, pp. 47-48.

18. Alter, The David Story, p. 25.

19. Gnana Robinson, Let Us Be Like the Nations: A Commentary on the Books of 1 and 2 Samuel (Edinburgh: Handsel Press, 1993), p. 33.

20. David Jobling, 1 Samuel (Berit Olam: Studies in Hebrew Narrative and Poetry; Collegeville, MN: Liturgical Press, 1998), p. 51. 
and litigation in ancient Israel. Bovati defines a judge as 'someone who, so to speak, embodies the judicial institution: an individual (or a college of individuals) to whom the task and power to make decisions for everybody has been entrusted' ${ }^{21}$ He also notes that judges sit to hear a case (and are characterized by the verb ישב) and then arise (קום) to give a final judgment. ${ }^{22}$ And he later notes that keeping silent in a lawsuit signified defeat, as it implicitly acknowledged that the other party was right. ${ }^{23}$ The fact that Eli never rises from his כסא, nor speaks again before his death, is certainly suggestive. With this in mind it is noticeable that Eli is characterized in this passage as a judge; he sits on a designated seat, by the city gates, and is named as having judged, which makes it rather ironic that he dies in the place where judgment would usually be given. In this reading, it seems that as Eli previously judged Israel, now Yahweh judges Eli and finds him to be at fault. If social order was linked to judgment and public displays in the city gates, then the death of a man who is said to have judged Israel being linked to the gate, suggests that the old social order is publicly judged to be unworthy by Yahweh, and a new one can now begin. Although this reading in its final conclusion will not be unknown to the reader, it is the role of the gate that allows the narrator to communicate this message clearly.

\section{The Death of Abner (2 Samuel 3.27)}

The Joab-Abner confrontation that comes to a climax with Abner's death in the gate in 2 Sam. 3.27, and ends some time later with Joab's death in $1 \mathrm{Kgs}$ 2.32-34, has been written on extensively in scholarly works. Most scholars agree that Joab is guilty of murder, or at least homicide, as it is thought that a blood feud should not have legally arisen between Joab and Abner, due to Asahel's death occurring in a battle scenario, as made clear by 2 Sam. 3.30. However, it has certainly not gone unnoticed that a potential rival to Joab was removed from the scene, and the timing, after Abner has made a covenant with David and sent word to the elders of Israel, is suspiciously fortunate for David. ${ }^{24}$ The subject of homicide and

21. Bovati, Re-Establishing Justice, p. 214.

22. Bovati, Re-Establishing Justice, pp. 232-35.

23. Bovati, Re-Establishing Justice, p. 342.

24. See, e.g., F.H. Cryer, 'David's Rise to Power and the Death of Abner: An Analysis of 1 Samuel XXVI 14-16 and its Redaction-Critical Implications', VT 35 (1985), pp. 385-94; N.P. Lemche, 'David's Rise', JSOT 10 (1978), pp. 2-25; George Nicol, 'The 
legal punishment has arisen from awareness of blood guilt and blood feud as well as the lack of immediate punishment for Joab. As Abner's death is portrayed as murder, the legal material of the time demanded Joab's death. ${ }^{25}$ Barmash's study of homicide gives a thorough treatment of the biblical and ancient Near Eastern sources, but on Joab's action she concludes that Joab is too powerful for David to execute him for the murder of Abner. ${ }^{26}$ Mein similarly notes that 'The king's servants are both the source of his power and the most potent threat'. ${ }^{27}$ It is an interesting point, and is clearly demonstrated in the case of Abner's betrayal of Ishbaal. As Janzen's recent article suggests, if David's words in $1 \mathrm{Kgs} 2.5$ are read as 'the things which he did for me' rather than the usual 'the things which he did to me', then we may have a clearer answer as to why David did not seek to punish Joab. ${ }^{28}$

But what is the role of the gate in this episode? Perhaps part of the answer can be seen in David's lament for Abner in 2 Sam. 3.33-34.

Death of Joab and the Accession of Solomon: Some Observations on the Narrative of 1 Kings 1-2', SJOT 7 (1993), pp. 134-51; James C. VanderKam, 'Davidic Complicity in the Deaths of Abner and Eshbaal: A Historical and Redactional Study', JBL 99 (1980), pp. 521-39; J.W. Wesselius, 'Joab's Death and the Central Theme of the Succession Narrative (2 Samuel IX-1 Kings II)', VT 40 (1990), pp. 336-51; David Janzen, “"What he did for me”: David's Warning about Joab in 1 Kings 2.5', JSOT 39 (2015), pp. 265-79; Daniel Friedmann, To Kill and Take Possession: Law, Morality and Society in Biblical Stories (Peabody, MA: Hendrickson, 2002), p. 155.

25. Pamela Barmash, 'The Narrative Quandry: Cases of Law in Literature', VT 54 (2000), pp. 1-16; idem, Homicide in the Biblical World (Cambridge: Cambridge University Press, 2005); Jonathan P. Burnside, God, Justice and Society: Aspects of Law and Legality in the Hebrew Bible (Oxford: Oxford University Press, 2011), p. 267; idem, 'Exodus and Asylum: Uncovering the Relationship Between Biblical Law and Narrative', JSOT 34 (2010), pp. 243-66; McKeating, 'The Development of the Law on Homicide'; David P. Wright, 'Homicide, Talion, Vengeance, and Psycho-Economic Satisfaction in the Covenant Code', in David A. Bernat and Jonathan Klawans (eds.), Religion and Violence: the Biblical Heritage (Recent Research in Biblical Studies, 2; Sheffield: Sheffield Phoenix Press, 2007), pp. 57-78; Tikva Frymer-Kensky, 'Tit for Tat: The Principle of Equal Retribution in Near Eastern and Biblical Law’, BA 49 (1980), pp. 23034; M.E.J. Richardson, Hammurabi's Law: Text, Translation and Glossary (Sheffield: Sheffield Academic Press, 2000).

26. Barmash, Homicide in the Biblical World, p. 34 n. 25.

27. Andrew Mein, 'Psalm 101 and the Ethics of Kingship', in Katharine Dell (ed.), Ethical and Unethical in the Old Testament: God and Humans in Dialogue (London: T\&T Clark International, 2010), pp. 56-70 (67).

28. Janzen, "“What he did for me", pp. 266-67. 
Scholars have sometimes interpreted the reference to Abner dying a fool's death, and not having his feet bound and fettered, as implying his foolishness (being a military general who should have known better) for allowing himself to be murdered so easily. ${ }^{29}$ However, given the role of the gate in the passing of judgment on and the execution of criminals, perhaps it makes better sense to view David's lament in this way. David is not so much lamenting that Abner is dead in these two verses, but rather how he has died - as a common criminal, executed in the city gate. The references to his hands and feet not being bound may serve as an attempt to distinguish his death from the others that would have taken place there - that is, that although Abner was killed in the gate, the people must be aware that he was not bound like a criminal, and he should not have been killed there. For a man of Abner's standing and military achievements to die in the gate would have been a shameful end, and perhaps this contributes to the efforts of David to bury Abner with a state burial and public mourning. Not only must David distance himself from the killing, but he must also separate himself from the manner in which it was done. It also may serve partially to explain the emphasis on shame in the curse David utters against the house of Joab - as Joab treated Abner shamefully, so too is his house cursed in shameful terms. ${ }^{30}$ The gate serves to throw a different light on the way in which Abner's death may have been perceived, and also functions as a literary law court. Two men enter into a form of disputation there and one is killed. But the dead man is perceived to be innocent by the author, as he makes sure to inform the reader that Joab is the guilty party. At first, a casual reader may have seen nothing wrong with Joab's actions; Joab puts Abner to death in the city gate as a result of the blood feud created by Asahel's death. There is even a talion approach in the method by which Joab kills Abner, 'by smiting him in the belly', as Abner killed Asahel, which Polzin terms 'a narrative

29. John Mauchline, 1 and 2 Samuel (New Century Bible; London: Marshall, Morgan \& Scott, 1971), p. 211; Auld, I and II Samuel, p. 383; William McKane, I and II Samuel: Introduction and Commentary (London: SCM Press, 1967), p. 194.

30. On the curse on Joab, see Steven W. Holloway, 'Distaff, Crutch or Chain-Gang: The Curse Against the House of Joab in 2 Samuel III 29', VT 37 (1987), pp. 370-75; T.M. Lemos, 'Shame and Mutilation of Enemies in the Hebrew Bible', JBL 125 (2006), pp. 225-41 (235). Slightly differently, see Lyn M. Bechtel, 'Shame as a Sanction of Social Control in Biblical Israel: Judicial, Political, and Social Shaming', JSOT 49 (1991), pp. 47-76 (53). 
patterning of murder' ${ }^{31}$ As Matthews says, 'the gate was the tie that bound the average citizen to the operations of his government and of the temple. And it was the symbol of the continuity of law and social stability. ${ }^{32}$ In the place symbolic of law and social stability, the narrator makes it clear that Joab commits a murder, rather than a legally approved execution. Instead of the guilty party dying in the gate, Joab's actions make him the guilty party. The fact that Joab commits such an act in the heart of the institution of legality and justice also perhaps serves as a metaphor for the chaos it threatens to cause in David's reign. As a general, Joab was an important part of David's ambitions. As an institution, the gate was a vital part of the city and of the perception of justice and order there. The clash between Joab/Abner, ambition/loyalty, and justice/murder makes the gate a natural setting for the narrative of the death of Abner.

\section{The Death of Jezebel (2 Kings 9.31-33)}

In 2 Kgs 9.31 Jehu is stated as entering the gate--ויהוא בא בשער. It is from here that Jezebel calls down to him and is eventually thrown down to be trampled and killed. It is not made clear in the passage whether the gate in question is a palace gate, as commonly assumed in commentaries, or whether it is the city gate. Williamson has noted that Jehu enters by the gate, from which a window of the royal residence was visible, and 'since when Jezebel is thrown down from this window, he tramples her underfoot on his way into the residence (vv. 33-34), we must assume that there was a space between the gate and the residence and that at this point, therefore, the residence itself was not directly built on the outside wall' ${ }^{33}$ Indeed, the excavations at Jezreel demonstrated that the gatehouse was a separate structure to the casemate walls, rather than bonded to them. ${ }^{34}$ However, 2 Kgs 9.17-20 narrates the sentinel of Jezreel being aware of a military force approaching and the sending out of two separate messengers to find out what they are doing. When they do not return, in

31. Robert Polzin, David and the Deuteronomist: A Literary Study of the Deuteronomic History, Part Three, 2 Samuel (Bloomington: Indiana University Press, 1993), p. 37.

32. Matthews, 'Entrance Ways', p. 26.

33. H.G.M. Williamson, 'Jezreel in the Biblical Texts', Tel Aviv 1 (1991), pp. 72-92.

34. David Ussishkin and John Woodhead, 'Excavations at Tel Jezreel, 1994-1996: Third Preliminary Report', Tel Aviv: Journal of the Institute of Archaeology of Tel Aviv University 24 (1997), pp. 6-72 (69). 
v. 21, Joram's instructions are to ready his chariot, and kings Joram and Ahaziah go forth (ויצא) to meet Jehu in their chariots..$^{35}$ Do we really believe our author that they went alone? This is not the action of a king casually meeting a returning general; the city was concerned enough to send a messenger, concerned again to send another, and then finally they ready their chariots and go forth (יצא), a verb often used in military contexts, to meet the approaching force. $\mathrm{Na}$ 'aman has also questioned the Kings account of an uncontested Jehu entrance, on the basis of the Iron Age arrowheads found around the gate and walls at Jezreel. ${ }^{36}$ On the basis of historical military action, I suggest it is plausible that the city gate of Jezreel would have been either shut until the king returned or left open until they saw that he would not return and then shut. As Jezebel remained alive in the city, it seems likely that once she realized the outcome she would have wanted the city gates shut, so that she could attempt to negotiate with Jehu from a position of strength. ${ }^{37}$ The archaeology of Jezreel demonstrates its strong defensive capabilities, which include a moat dug around the site, which would presumably have been crossed by a bridge or drawbridge of some kind, though no remains of one were found. ${ }^{38}$ Shutting the gate would have left Jehu needing either to enter a state of siege with Jezreel or to rely on the people giving up Jezebel, which as it turns out, they did. But perhaps this also is why she is thrown from the window - because the city gates were closed. To be sure, this is speculation, but I find it more plausible than presupposing that a city who had seen a hostile force approach and had its king ride out to meet it, would have opened their gates immediately and let Jehu enter and ride straight up to the (unmentioned) palace. Thus I suggest that Jezebel died at, or in, the gates of the city.

Elijah's oracle in $1 \mathrm{Kgs} 21.17-24$ proclaims Jezebel's death by being eaten by dogs as a judgment from Yahweh because Jezebel and Ahab have 'sold themselves to do evil'. The message from the young prophet in

35. On the military effectiveness and use of chariots in the Iron Age, see Deborah O'Daniel Cantrell, The Horsemen of Israel: Horses and Chariotry in Monarchic Israel (Ninth-Eighth Centuries BCE) (History, Archaeology and Culture of the Levant; Winona Lake, IN: Eisenbrauns, 2011).

36. N. Na'aman, 'Historical and Literary Notes on the Excavations at Tel Jezreel', Tel Aviv 24 (1997), pp. 122-28 (126).

37. On tactics of siege warfare and characteristics, see Israel Eph'al, The City Besieged: Siege and its Manifestations in the Ancient Near East (CHANE, 36; Leiden: Brill, 2009), pp. 1, 102.

38. Ussishkin and Woodhead, 'Excavations at Tel Jezreel', p. 69. 
2 Kgs 9.1-10 reiterates the judgment, although this time it is more clearly stated as vengeance for the blood of the prophets and servants of Yahweh (v. 7). Jezebel's death at the gate fulfils the prophecies as, no doubt, our narrator intended. ${ }^{39}$ Jezebel is judged by Yahweh to be deserving of death and dies appropriately in the place of judgment. Nielsen has noted that Yahweh uses dogs to punish in Jer. 15.3, but more generally they are used elsewhere because they are despised. She notes that we are used to seeing bodies of enemies left unburied on the open field, and that the themes in 1 Kings 20-21 are paralleled in $1 \mathrm{Kgs} 14.11$ with Jeroboam's kin. ${ }^{40}$ The dogs devouring Jezebel's body is ironically mirrored in Jehu's eating; as he eats to sustain himself, so the dogs devour Jezebel, rendering her less than a person. ${ }^{41}$ Just as her death at the gate cuts her off from the community in life, so too the failure to bury her and the mutilation of her body ensures that she is cut off from the community in death as well.

There may be further irony here with the image of the woman at the window falling to her death in the gate. As many have noted, Jezebel being described in a window puts her in a literary line with a few other women in the biblical texts (Sisera's mother, Michal, Rahab), and also in conversation with the woman in the window reliefs found at Khorsabad, Arslan Tash, Nimrud and Samaria. ${ }^{42}$ The woman in the reliefs seems likely to be cultic, perhaps a goddess, if the triple recessed window is anything to go by, as triple recessed doors were a known feature of

39. E.g. Burke O. Long, 2 Kings (Grand Rapids, MI: Eerdmans, 1991), p. 129; John Gray, I and II Kings (London: SCM Press, 1964), p. 495; Donald J. Wiseman, 1 and 2 Kings (Leicester: Inter-Varsity Press, 1993), p. 223; Volkmar Fritz, 1 \& 2 Kings: A Continental Commentary (Minneapolis: Fortress Press, 2003), p. 287.

40. Kirsten Nielsen, 'Construction of Meaningful Contexts on War, Lions, Dogs, Birds and a Vineyard', SJOT 21 (2007), pp. 218-27.

41. Robert L. Cohn, 2 Kings (Berit Olam: Studies in Hebrew Narrative and Poetry; Collegeville, MN: Liturgical Press, 2000), p. 70.

42. Don Seeman, 'The Watcher at the Window: Cultural Poetics of a Biblical Motif', Prooftexts 24 (2004), pp. 1-50; Susan Ackerman, Warrior, Dancer, Seductress, Queen: Women in Judges and Biblical Israel (London: Yale University Press, 2009), p. 161; Eleanor F. Beach, 'The Samaria Ivories, Marzeah, and the Biblical Text', BA 55 (1992), pp. 130-39; Judith E. McKinlay, 'Negotiating the Frame for Viewing the Death of Jezebel', BibInt 10 (2002), pp. 305-23; Tina Pippin, 'Jezebel Re-Vamped', in Athalya Brenner (ed.), A Feminist Companion to Samuel and Kings (The Feminist Companion to the Bible, 5; Sheffield: Sheffield Academic Press, 1994), pp. 196-208; Nehama Aschkenasy, Woman at the Window: Biblical Tales of Oppression and Escape (Detroit, MI: Wayne State University Press, 1998), pp. 13-18. 
Mesopotamian temples. ${ }^{43}$ Whether the woman at the window in biblical literature is drawing off these ideas is rather more difficult to ascertain; Fritz for one thinks it is not, arguing that the biblical motifs do not have to be connected with the reliefs. ${ }^{44}$ However, one of Jezebel's defining characteristics in the biblical narratives is her association with foreign religion and with killing prophets of Yahweh $(1 \mathrm{Kgs} 16.31 ; 18.4,19)$, and so I suggest that Ackerman (and others) are correct to identify her with a representation of a foreign practice, most likely with cultic connections. The strength of the argument is perhaps better found in the image of Jezebel styling her hair and make-up and then standing in the window, rather than her simply standing in the window, as the reliefs depict a woman with a carefully done hairstyle. Here we could compare this to Michal, Rahab and Sisera's mother-where no such styling and presentation is mentioned. As Ackerman has suggested, if the queen in the window (Jezebel) is a mirror of the goddess in her temple, then Jezebel's fall from the window takes on new significance. As Aschkenasy says, 'the woman at the window highlights her removal from history'. ${ }^{45}$ As she falls from window to gate she falls from queen to less than a person, and, if her presence at the window mirrors a goddess, then the goddess ideas and imagery fall with her, to be crushed under the hooves of Jehu's horses at the behest of Yahweh himself, in the place of his judgment. Her chaotic and unjust rule is ended and a new order, sanctioned by Yahweh, can now begin.

\section{Conclusions}

This study has focused on the role of the gate in biblical narratives in which a notable character is reported as having died in a gate. The functions of city gates have been studied from archaeological, sociohistorical, comparative biblical/ancient Near Eastern, and biblical memory perspectives, but until now, have not yet been applied to biblical narratives on a literary level. ${ }^{46}$ In all three examples we have seen that there is an intertwining of gates and themes of judgment and punishment in the literary construction of the narrative, often leaving an ironic

43. Ackerman, Warrior, Dancer, p. 155.

44. Fritz, $1 \& 2$ Kings, p. 286.

45. Aschkenasy, Woman at the Window, p. 18.

46. May, 'Gates and their Functions'; Walsh, 'Testing Entry'. 
message behind. ${ }^{47}$ With Eli and Jezebel, Yahweh acts through his word and through the gates as the judge, though ironically he never appears explicitly as a judge in the narratives. With Joab and Abner in 2 Sam. 3.27 we see the gate acting more as a marker of situational irony than a judgment of Yahweh. ${ }^{48}$ Some scholars have identified justice and ethics as having implications for the conceptions of order and chaos in ancient Israel. ${ }^{49}$ If the gate functions as a symbol of legality, justice and order, as I have argued above, then a notable character dying in a gate in biblical narrative surely signals that deeper ideas and meanings are at work than we otherwise might have realized. As Noort has said on death, 'the final conclusion must be that there was a great deal of awareness of death in the daily life of ancient Israel' ${ }^{50}$ By combining socio-historical studies of city gates with literary analysis, this article has shown that the intertwining of gates, death and judgment in the ancient world allowed the narrator to draw on these themes for his own literary purposes including the creation of irony.

47. Fuller discussions of irony in the biblical texts can be found in Edwin M. Good, Irony in the Old Testament (London: SPCK, 1965); Ze'ev Weisman, Political Satire in the Bible (SBLSS; Atlanta: Scholars Press, 1998); J.W. Whedbee, The Bible and the Comic Vision (Cambridge: Cambridge University Press, 1982); Carolyn Sharp, Irony and Meaning in the Hebrew Bible (Bloomington: Indiana University Press, 2009); Lillian Klein, The Triumph of Irony in the Book of Judges (Sheffield: Almond Press, 1988); Yehuda T. Radday and Athalya Brenner (eds.), On Humour and the Comic in the Hebrew Bible (Bible and Literature, 23; Sheffield: Sheffield Academic Press, 1990); Athalya Brenner, On Feminism, Anger and Humour in Biblical Studies (Nijmegen: Katholieke Universiteit, 1994); Glenn Stanfield Holland, Divine Irony (London: Associated University Presses, 2000); Brian C. Jones, Howling Over Moab: Irony and Rhetoric in Isaiah 15-16 (SBLDS, 157; Atlanta: Scholars Press, 1996). For a useful discussion of irony more generally, see Joseph A. Dane, The Critical Mythology of Irony (Athens, GA: University of Georgia Press, 1991); Candace D. Lang, Irony/Humour: Critical Paradigms (Baltimore: The Johns Hopkins University Press, 1988); Wayne C. Booth, A Rhetoric of Irony (London: University of Chicago Press, 1974).

48. Douglas Muecke, The Compass of Irony (London: Methuen, 1969), p. 42.

49. John Barton, Ethics in Ancient Israel (Oxford: Oxford University Press, 2014), p. 104.

50. Ed Noort, 'Death and Justice: Shifting Paradigms in the Hebrew Bible and Early Judaism', in Dell (ed.), Ethical and Unethical, pp. 255-70 (256). See also Elizabeth Bloch-Smith, Judahite Burial Practices and Beliefs about the Dead (JSOTSup, 123; Sheffield: JSOT Press, 1992), especially her discussion of the significance of graves (pp. 111-18) and of people retaining their powers after death (pp. 111, 122). 